\title{
Pengaruh Leverage, Profitabilitas, Likuiditas, Ukuran Perusahaan, Dan Umur Perusahaan Terhadap Pengungkapan Laporan Keuangan
}

\author{
Hanifah Nur Azzahra ${ }^{1}$, Kuswatun Hasanah ${ }^{2}$, Dirvi Surya Abbas ${ }^{3}$ \\ Universitas Muhammadiyah Tangerang ${ }^{1,2,3}$ \\ Azzahrahanifah11@gmail.com
}

\begin{abstract}
Abstrak: Penelitian ini bertujuan untuk mengetahui pengaruh leverage, profitabilitas, likuiditas, ukuran perusahaan, dan umur perusahaan terhadap pengungkapan laporan keuangan pada Perusahaan Manufaktur Sektor Industri Barang Konsumsi yang terdaftar di Bursa Efek Indonesia pada tahun 2017-2018. Indikator pengungkapan laporan keuangan yang digunakan adalah penelitian uji hipotesis dengan menggunakan alat uji regresi data panel. Populasi dalam penelitian ini dalah perusahaan manufaktur yang terdaftar di Bursa Efek Indonesia dengan pengambilan sampel menggunakan purpose sampling.sampel yang digunakan dalam ppenelitian ini berjumlah 20 perusahaan. Hasil penelitian menunjukkan bahwa dalam uji parsial, profitabilitas memiliki pengaruh positif terhadap pengungkapan laporan keuangan, sedangkan leverage, likuiditas ukuran perusahaan, dan umur perusahaan tidak memiliki pengaruh terhadap pengungkapan lapora keuangan.
\end{abstract}

Kata Kunci: pengungkapan laporan keuangan, leverage, profitabilitas, likuiditas, ukuran perusahaan, umur perusahaan.

Kondisi lingkungan ekonomi telah banyak berubah dan sangat berpengaruh pada dunia usaha. Pada hakikatnya semua perusahaan memiliki tujuan utama yang sama, yaitu memperoleh laba yang sebesarbesarnya. Untuk dapat bertahan dalam persaingan, perusahaan diharapkan lebih transparan dalam melakukan pengungkapkan informasi perusahaannya, hal ini bertujuan untuk membantu para pengambil keputusan dalam menentukan keputusannya. Dalam hal ini, perusahaan dapat mengungkapkan informasinya dalam bentuk laporan keuangan.

Adanya fenomena mengenai pengungkapan laporan keuangan perusahaan yang ada di BEI masih ada yang belum lengkap yang seringkali melibatkan kerugian bagi stakeholder. Sepanjang tahun 2018, tercatat sebanyak 46 kasus terkait dengan pasar modal, dengan 24 kasus diantaranya merupakan kasus terkait emiten dan perusahaan publik. Beberapa kasus diantaranya 303 sanksi denda administrasi, 179 sanksi administrasi peringatan tertulis, 3 sanksi administrasi pencabutan izin, dan 3 perintah tertulis kepada perusahaan. Menurut Djustini Septiana selaku Deputi Komisioner Pengawas Pasar Modal I OJK, pemeriksaan terhadap emiten terutama karena adanya keterlambatan pelaporan baik reguler, berkala maupun keterbukaan informasi dan juga pelanggaran terhadap transaksi saham.

Menurut Sampurno (2016) dalam Dewi dan Ratih (2018), Laverage yang merupakan tingkat hutang perusahaan yang merupakan hal penting bagi laporan perusahaan yang harus di laporkan. Perusahaan yang memiliki rasio hutang tinggi akan termotivasi untuk mengungkapkan 
informasi lebih banyak, luas dan komprehensif dibandingkan dengan perusahaan yang memiliki rasio leverage yang rendah. Dari penelitian yang dilakukan oleh Kartika (2009) memperoleh hasil bahwa leverage memiliki pengaruh positif terhadap pengungkapan laporan keuangan, sedangkan hasil penelitian Nugroho (2018) leverage memiliki pengaruh negatif terhadap pengungkapan laporan keuangan.

Menurut Pradifta (2014) dalam Dewi dan Ratih (2018) kebanyakan investor menyukai perusahaan dengan profitabilitas yang tinggi, dengan harapan perusahaan tersebut mampu memberikan pengembalian dana investasi yang tinggi pula. Perusahaan dengan tingkat profitabilitas yang tinggi akan memberikan signal kepada para investor melalui pengungkapan laporan keuangan agar investor tertarik untuk berinvestasi. Dari hasil penelitian yang dilakukan oleh Nugroho (2018) profitabilitas memiliki pengaruh terhadap pengungkapan laporan keuangan, sedangkan hasil penelitian Maharani dan Budiasih (2016) menunjukkan bahwa profitabilitas tidak berpengaruh terhadap pengungkapan laporan keuangan.

Menurut Sartono (2001) dalam Pratiwi (2015) Tingginya tingkat likuiditas pada sebuah perusahaan mencerminkan kemampuan perusahaan dalam hal memenuhi kewajiban jangka pendeknya. Perusahaan yang memiliki likuiditas tinggi cenderung akan menyampaikan laporan keuangannya secara tepat waktu dan hal ini akan berdapak pada reaksi pasar yang akan menilai positif terhadap perusahaan tersebut. Dari hasil penelitian Agustina (2017) likuiditas memiliki pegaruh positif terhadap pengungkapan laporan keuangan, sedangkan hasil penelitian Santioso dan Yenny (2012) menunjukkan bahwa likuiditas memiliki pengaruh negatif terhadap pengungkapan laporan keuangan.

Menurut Jensen dan Meckling (1976) dalam Maharani dan Budiasih (2016) menjelaskan bahwa perusahaan yang besar memiliki biaya agensi (agency cost) lebih besar dibandingkan perusahaan kecil. Untuk mengurangi biaya agensi, perusahaan akan mengungkapkan lebih banyak informasi atau akan melakukan pengungkapan yang lebih luas. Dari hasil penelitian Santioso dan Yenny (2012) ukuran perusahaan memiliki pengaruh terhadap pengungkapan laporan keuangan, sedangkan hasil penelitian Maharani dan Budiasih (2016) menunjukkan bahwa ukuran perusahaan tidak memiliki pengaruh terhadap pengungkapan laporan keuangan.

Menurut Santioso dan Yenny (2012) Umur perusahaan merupakan cerminan dari seberapa lama perusahaan mampu bertahan. Perusahaan yang sudah lama berdiri memiliki pengalaman yang lebih banyak dalam mempublikasikan informasi perusahaannya. Perusahaan yang memiliki pengalaman lebih banyak, akan lebih mengetahui kebutuhan pemakai informasi perusahaannya. Dari hasil penelitian Kartika (2009) umur perusahaan memiliki pengaruh terhadap pengungkapan laporan keuangan, sedangkan hasil penelitian Dewi dan Ratih (2018) 
menunjukkan bahwa umur perusahaan tidak memiliki pengaruh terhadap pengungkapan laporan keuangan.

Berdasarkan pemikiran diatas maka penulis memutuskan untuk melakukan penelitian dengan judul "Pengaruh Leverage, Profitabilitas, Likuiditas, Ukuran Perusahaan, dan Umur Perusahaan Terhadap Pengungkapan laporan keuangan (Studi Empiris Pada Perusahaan Manufaktur Sektor Industri Barang Konsumsi yang terdaftar di BEI tahun 2017 - 2018)". Berdasarkan uraian latar belakang diatas, maka penelitian ini dapat dirumuskan dalam bentuk pertanyaan penelitian sebagai berikut: Apakah leverage, profitabilitas, likuiditas, ukuran perusahaan, dan umur perusahaan berpengaruh terhadap pengungkapan laporan keuangan? Sesuai dengan latar belakang dan rumusan masalah, maka tujuan penelitian ini adalah: untuk membuktikan secara empiris pengaruh leverage, profitabilitas, likuiditas, ukuran perusahaan, dan umur perusahaan terhadap pengungkapan laporan keuangan.

\section{METODE}

\section{A. Jenis Penelitian}

Penelitian ini adalah penelitian kuantitatif karena menggunakan data sekunder yang diperoleh dari laporan keuangan tahunan yang ada di Bursa Efek Indonesia (BEl) pada sektor manufaktur sektor industri barang konsumsi yang diperoleh dari website http://www.idx.co.id, tahun 2017-2018.

\section{B. Definisi dan Pengukuran Variabel \\ 1. Pengungkapan Laporan Keuangan}

Pada penelitian ini variabel dependen yang digunakan adalah pengungkapan laporan keuangan yang diukur menggunakan instrumen Wallace serta menggunakan indeks untuk mengukur berapa banyak laporan keuangan yang diungkap oleh perusahaan. Semakin banyak item yang diungkap oleh perusahaan, semakin besar angka indeks yang diperoleh perusahaan. (Nugroho, 2018) Pengukuran tersebut dilakukan dengan cara mengamati ada tidaknya suatu item yang ditemukan dalam laporan tahunan (Pundawuri, 2012). Apabila suatu emiten menyajikan laporan keuangan maka diberikan poin 1. Apabila suatu emiten tidak menyajikan laporan keuangan maka diberikan nilai 0. Dan skor yang diperoleh tiap perusahaan sampel kemudian dijumlahkan untuk mendapatkan skor total. Kemudian skor total dibagi dengan jumlah item yang seharusnya diungkap. Angka indeks dihitung sebagai berikut:

Keterangan:

$$
\text { Indeks }=\frac{n}{k}
$$

$\mathrm{n}$ : jumlah item yang diungkap oleh perusahaan

k: jumlah item yang seharusnya diungkap

\section{Leverage}

Leverage menunjukkan seberapa besar perusahaan dapat memberikan jaminan pada hutangnya. Untuk mengukur leverage diukur 
menggunakan Debt To Equity Ratio dengan rumus: (Palepu, 2004 dalam Pratiwi 2015)

\section{Profitabilitas}

$$
D E R=\frac{\text { Short Term Debt }+ \text { Long Term Debt }}{\text { Total Equity }}
$$

Profitabilitas bertujuan untuk mengukur kemampuan perusahaan untuk memperoleh laba. Rasio profitabilitas diukur menggunakan rasio Return On Asset (ROA). Dengan rumus: (Palepu, 2004 dalam Pratiwi 2015)

\section{Likuiditas}

$$
R O A=\frac{\text { Earning After Tax }}{\text { Total Asset }}
$$

Likuiditas menunjukkan kemampuan perusahaan dalam emenuhi hutang jangka pendek atau kewajiban lancarnya yang segera akan jatuh tempo. Likuiditas dalam penelitian ini menggunakan Current Ratio dengan rumus: (Kieso et al, 2011 dalam Pratiwi 2015)

\section{Ukuran Perusahaan}

$$
C R=\frac{\text { Current Asset }}{\text { Current Liabilities }}
$$

Ukuran perusahaan merupakan variabel yang digunakan untuk mengukur seberapa besar atau kecilnya perusahaan. Pengukuraan ukuran perusahaan dihitung menggunakan log natural dari aset total perusahaan (Januarti, 2009 dalam Susanti 2013)

\section{Umur Perusahaan}

$$
\text { Ukuran Perusahaan }=\operatorname{Ln}(\text { Total Asset })
$$

Umur Perusahaan merupakan variabel yang dapat dihitung sejak perusahaan tersebut berdiri berdasarkan akta pendirian hingga sekarang. Dengan rumus (Sampurno, 2015 dalam Dewi dan Ratih, 2017)

$$
\text { UMUR = Tahun First Issue }- \text { Tahun Berdiri }
$$

\section{Metode Pengambilan Sampel}

Sampel dalam penelitian ini yaitu perusahaan manufaktur sektor industri barang konsumsi yang terdaftar pada Bursa Efek Indonesia (BEI) selama periode tahun 2017 - 2018. Metode pemilihan sampel yang digunakan adalah purposive sampling. Dengan kriteria sampel sebagai berikut:

1. Perusahaan Manufaktur sektor industri barang konsumsi yang terdaftar di BEI periode tahun 2017-2018.

2. Perusahaan yang menerbitkan laporan keuangannya dengan lengkap, di audit dan mempublikasikan laporannya pada tahun 2017-2018.

3. Perusahaan yang konsisten di listing

4. Perusahaan yang menggunakan mata uang Rupiah dan tidak menggunakan mata uang asing dalam laporan keuangannya.

5. Perusahaan yang menghasilkan laba bersih selama tahun 2017-2018.

6. Perusahaan yang memiliki saham syariah antara tahun 2017-2018. 


\section{Metode Pengumpulan Data}

Metode pengambilan data dalam penelitian ini adalah metode dokumentasi yaitu dengan cara mengumpulkan data-data dan dokumendokumen yang berhubungan dengan penelitian ini. Data yang digunakan dalam penelitian ini adalah laporan keuangan perusahaan manufaktur sub sektor makanan \& minuman periode tahun 2017-2018 yang terdaftar di Bursa Efek Indonesia (BEI).

\section{E. Metode Analisis Data}

Dalam penelitian ini, teknik analisis data yang digunakan yaitu analisis regresi data panel dengan bantuan software pengolah data eviews 9. Adapun metode analisis yang digunakan adalah:

\section{Analisis Statistik Deskriptif}

Statistik deskriptif digunakan pada penelitian ini untuk memberikan informasi mengenai karakteristik variabel penelitian utama. Statistik deskriptif terdiri dari mean, median, maximum, minimum, standard deviation, skewness, kurtosis, jarque-bera, probability (Eksandy, 2018).

\section{Analisis Regresi Data Panel}

Prinsip data panel adalah gabungan antara data time series dengan data scross section. Data panel disebut pula data longitudinal atau data runtut waktu silang (time series - scross section) yang diamati pada dua periode waktu atau lebih yang diindikasikan dengan penggunaan beberapa periode data time series (Sriyana, $2014: 77$ ) dalam buku (Eksandy, 2018). Adapun persamaan regresi data panel sebagai berikut:

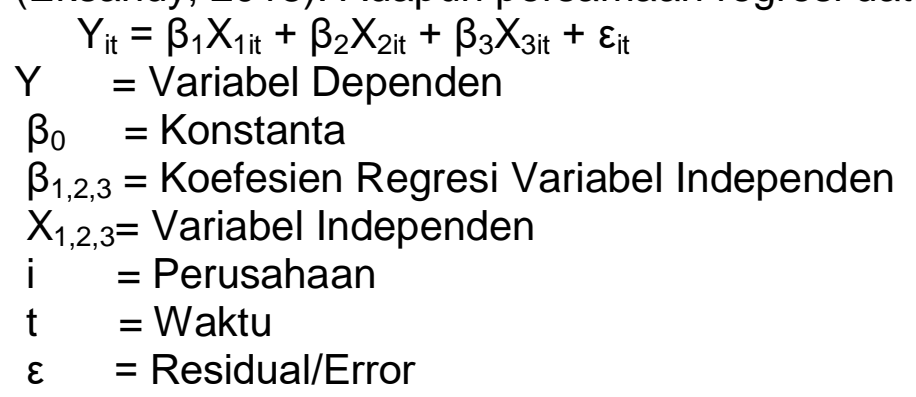

Model regresi data panel terbagi menjadi 3 model yaitu Common Effects Model (CEM), Fixed Effects Model (FEM), Random Effects Model (REM).

\section{Teknik Pemilihan Model Regresi Data Panel}

\section{a. Uji Chow}

Pengujian ini dapat dilihat pada nilai Probabilitas (Prob.) Cross-section F dan Cross-section chi-square dengan hipotesis berikut:

$\mathrm{HO}$ : Model mengikuti CEM jika Prob. Crosssection $\mathrm{F}$ dan Cross-section chi-square $>$ a $(0,05)$

$\mathrm{Ha}$ : Model mengikuti FEM jika Prob. Crosssection $\mathrm{F}$ dan Cross-section chi-square $<a(0,05)$

\section{b. Uji Hausman}

Pengujian ini dapat dilihat pada nilai Prob. Cross-section random dengan hipotesis sebagai berikut:

$\mathrm{HO}$ :Model mengikuti REM jika Prob. Cross- 
section random $>$ a $(0,05)$

$\mathrm{Ha}$ :Model mengikuti FEM jika Prob. Cross-

section random $<$ a $(0,05)$

\section{c. Uji Lagrange Multiplier}

Pengujian ini dapat dilihat pada nilai Prob. Breush-pagan dengan hipotesis berikut:

HO : Model mengikuti CEM jika Prob. Cross-section Breush- pagan > a $(0,05)$

$\mathrm{Ha}$ : Model mengikuti REM jika nilai Prob. Cross-section Breush-pagan < a $(0,05)$

\section{Uji Asumsi Klasik}

Uji asumsi klasik adalah persyaratan statistik yang harus dipenuhi pada analisis regresi dengan pendekatan Ordinary Least Squared (OLS). Dengan demikian perlu dilakukan uji asumsi klasik apabila model regresi yang digunakan dalam bentuk CEM atau FEM. Sebaliknya, apabila persamaan regresi lebih cocok menggunakan REM, maka tidak perlu dilakukan uji asumsi klasik. Dalam uji asumsi klasik yang dilakukan dalam regresi data panel menggunakan Uji Multikolinieritas dan Heteroskedastisitas.

\section{Uji Hipotesis}

\section{Uji Kelayakan Model (Uji F)}

Uji F digunakan untuk menjelaskan apakah semua variabel bebas yang dimasukkan kedalam model secara bersama-sama mempunyai pengaruh terhadap variabel terikat. Hipotesis dalam uji $F$ adalah sebagai berikut:

a. Berdasarkan perbandingan F-statistik dengan $\mathrm{F}$ tabel

$\mathrm{HO}$ : Jika nilai F-statistik < F Tabel

$\mathrm{Ha}$ : Jika nilai F-statistik > F Tabel

b. Berdasarkan probabilitas

$\mathrm{HO}$ : Jika nilai Prob (F-statistic) > a 0,05

$\mathrm{Ha}$ : Jika nilai Prob (F-statistic) < a 0,05

2. Uji $\mathbf{R}^{2}$ (Koefesien Determinasi)

Hasil koefisien determinasi menjelaskan seberapa jauh kemampuan model regresi dalam menerangkan variasi variabel bebas mempengaruhi variabel terikat. Nilai R-squared berada antara 0 sampai 1 dengan penjelasan sebagai berikut:

- Nilai R-squared harus berkisar 0 sampai 1.

- Jika nilai R-squared sama dengan 1, berarti naik atau turunnya variabel terikat $(Y)$ 100\% dipengaruhi oleh variabel bebas $(X)$.

- Jika nilai R-squared sama dengan 0,berarti tidak ada hubungan sama sekali antara variabel independen terhadap variabel dependen.

\section{Uji t}

Hasil uji t menjelaskan signifikansi pengaruh variabel bebas secara parsial terhadap variabel terikat. Hipotesis dalam uji t adalah sebagai berikut:

a. Berdasarkan perbandingan t-statistic dengan t tabel: 
$\mathrm{HO}:$ Jika nilai t-statistic $<\mathrm{t}$ tabel

$\mathrm{Ha}$ : Jika nilai t-statistik $>\mathrm{t}$ tabel

b. Berdasarkan probability

$\mathrm{HO}$ : Jika nilai Prob. $>$ a $(0,05)$

$\mathrm{Ha}$ : Jika nilai Prob. $<\mathrm{a}(0,05)$

\section{HASIL}

\section{A. Analisis Statistik Deskriptif}

Statistik deskriptif yang ditunjukkan dengan nilai Mean, Median, Maximum, Minimum, Standard Deviation, Skewness, Kurtosis, dan Jarque-Bera berfungsi untuk mengetahui karakteristik data dari masing-masing variable yang digunakan. Berikut hasil analisis statistik deskriptif :

\begin{tabular}{|c|c|c|c|c|c|c|}
\hline \multicolumn{7}{|c|}{$\begin{array}{l}\text { Date: 06/17/20 Time: } 22 \cdot 55 \\
\text { Sample: } 20172018\end{array}$} \\
\hline & $Y$ & x05 & $x_{04}$ & x03 & $x_{02}$ & x01 \\
\hline Mean & 0.812500 & 0.676500 & 0.176700 & 2709950 & 28.98785 & 19.80000 \\
\hline Median & 0.800000 & 0.434000 & 0.077000 & 2.597000 & 28.88050 & 17.00000 \\
\hline Maximum & 1000000 & 2330000 & 1500000 & 5.759000 & 32.20000 & 4900000 \\
\hline Minimum & 0.700000 & 0.040000 & 0.028000 & 0.748000 & 26.92000 & 1.000000 \\
\hline Std. Dev. & 0.097164 & 0616478 & 0.327015 & 1.517341 & 1.399273 & 12.58905 \\
\hline Skewness & 0.344924 & 1. 364187 & 3.582423 & 0.489420 & 0.529350 & 0.512416 \\
\hline Kurtosis & 1.861441 & 3.971023 & 14.90786 & 2.014883 & 2.698470 & 2.718013 \\
\hline Jarque-Bera & 1.476840 & 6.989091 & 160.9434 & 1.607153 & 1.009804 & 0.941496 \\
\hline Probability & 0.477868 & 0.030363 & 0.000000 & 0.447725 & 0603565 & 0.624535 \\
\hline Sum & 16.25000 & 13.53000 & 3.534000 & 54.19900 & 579.7570 & 396.0000 \\
\hline Sum Sq. Dev. & 0.179375 & 7.220057 & 2.031836 & 43.74414 & 37.20134 & 3011.200 \\
\hline Observations & 20 & 20 & 20 & 20 & 20 & 20 \\
\hline
\end{tabular}

B. Teknik Pemilihan Model Regresi dara Panel

1. Uji Chow

\begin{tabular}{|c|c|c|c|}
\hline Effects Test & Statistic & d.f. & Prob. \\
\hline $\begin{array}{l}\text { Cross-section F } \\
\text { Cross-section Chi-square }\end{array}$ & $\begin{array}{r}1.167060 \\
22.632605\end{array}$ & $\begin{array}{r}(9,5) \\
9\end{array}$ & $\begin{array}{l}0.4559 \\
0.0571\end{array}$ \\
\hline
\end{tabular}

Berdasarkan tabel diatas, nilai Probabilitas Cross-section F dan Crosssection chi-square > (0.05), maka dapat disimpulkan bahwa Common Effect Model (CEM) lebih layak digunakan dibandingkan Fixed Effect Model (FEM).

\section{Uji Hausman}

\begin{tabular}{|c|c|c|c|}
\hline Test Summary & Chi-Sq. Statistic & Chi-Sq. d.f. & Prob. \\
\hline Cross-section random & 6.492943 & 5 & 0.2612 \\
\hline
\end{tabular}

Berdasarkan hasil perhitungan diatas nilai probabilitas (Prob.) Crosssection random > (0.05), maka dapat disimpulkan bahwa Random Effect Model (REM) lebih layak digunakan dibandingkan Fixed Effect Model (FEM). 
3. Uji Lagrange Multiplier

\begin{tabular}{|c|c|c|c|}
\hline $\begin{array}{l}\text { Null (no rand. effect) } \\
\text { Alternative }\end{array}$ & $\begin{array}{l}\text { Cross-section } \\
\text { One-sided }\end{array}$ & $\begin{array}{l}\text { Period } \\
\text { One-sided }\end{array}$ & Both \\
\hline Breusch-Pagan & $\begin{array}{l}0.906096 \\
(0.3412)\end{array}$ & $\begin{array}{l}1.094690 \\
(0.2954)\end{array}$ & $\begin{array}{l}2.000786 \\
(0.1572)\end{array}$ \\
\hline Honda & .951891 & $\begin{array}{c}-1.046274 \\
(0.8523)\end{array}$ & $\begin{array}{c}-1.412916 \\
(0.9212)\end{array}$ \\
\hline King-Wu & $\begin{array}{l}-0.951891 \\
(0.8294)\end{array}$ & $\begin{array}{l}-1.046274 \\
(0.8523)\end{array}$ & $\begin{array}{c}-1.293597 \\
(0.9021)\end{array}$ \\
\hline GHM & $\overline{-}$ & $=$ & $\begin{array}{l}0.000000 \\
(0.7500)\end{array}$ \\
\hline
\end{tabular}

Berdasarkan hasil perhitungan diatas nilai Probabilitas Cross-section Breusch-Pagan > $(0,05)$, maka dapat disimpulkan bahwa Common Effect Model (CEM) lebih layak digunakan dibandingkan Random Effect Model (REM).

4. Kesimpulan Model Regresi Data Panel

Berdasarkan hasil ke tiga pengujian yang sudah dilakukan maka dapat disimpulkan bahwa Model Regresi Data Panel yang akan

$\begin{array}{llclr}\text { No } & \text { Metode } & \text { Pengujian } & \text { Hasil } & \text { dagunakan } \\ 1 & \text { Uji Chow } & \text { CEM vs FEM } & \text { CEM } & \text { Hipotesis dan } \\ 2 & \text { Uji Hausman } & \text { REM vs FEM } & \text { REM } & \begin{array}{r}\text { persamaan } \\ \text { Regresi Data }\end{array} \\ 3 & \text { Uji Lagrange } & \text { CEM vs REM } & \text { CEM } & \text { Panel adalah } \\ \text { model }\end{array}$

digunakan

Common Effect Model (CEM).

C. Uji Asumsi Klasik

1. Uji Multikolineritas

\begin{tabular}{|c|c|c|c|c|c|}
\hline & X05 & X04 & X03 & X02 & X01 \\
\hline X05 & & & & & \\
\hline X04 & 0.252378 & 1.000000 & -0.293367 & 0.082649 & 73291 \\
\hline X03 & -0.280421 & -0.293367 & 1.000000 & -0.228177 & -0.034800 \\
\hline X02 & 0.504869 & 0.082649 & -0.228177 & 1.000000 & -0.138594 \\
\hline x01 & 0.268411 & 0.073291 & -0.034800 & -0.138594 & 1.000000 \\
\hline
\end{tabular}

Dari output di atas dapat dilihat tidak terdapat variabel independen yang memiliki nilai lebih dari 0.8 , sehingga dapat disimpulkan tidak terjadi multikolinearitas dalam model regresi.

\section{Uji Heteroskedastisitas}

\begin{tabular}{l|lrl}
\hline \multicolumn{1}{c}{ Test } & Statistic & di & Prob \\
\hline \hline Breusch Pagan LX & 61.29359 & 45 & 0.0533 \\
Pesaran scasod L & 1717455 & & 0.0859 \\
Pesaran CD & 3007231 & & 0.0026 \\
\hline \hline
\end{tabular}

Dari output diatas dapat dilihat nilai Prob. Breusch-Pagan LM sebesar $0.0533>0.05$, maka dapat disimpulkan bahwa model regresi data panel tidak terjadi heteroskedastisitas.

\section{Uji Hipotesis}

1. Uji F

\begin{tabular}{|c|c|c|c|}
\hline $\begin{array}{l}\text { R-squared } \\
\text { gression } \\
\text { ared resid } \\
\text { head }\end{array}$ & $\begin{array}{l}0.529408 \\
0.361339 \\
0.077650 \\
0.084412 \\
2620895\end{array}$ & $\begin{array}{l}\text { Mean dependent var } \\
\text { S.D. dependent var } \\
\text { Akaike info criterion } \\
\text { Schwarz criterion } \\
\text { Hannan-Quinn criter. }\end{array}$ & $\begin{array}{r}0.812500 \\
0.097164 \\
-2.029895 \\
-1.731176 \\
-1.971582 \\
\end{array}$ \\
\hline $\begin{array}{l}\text { F-statistic } \\
\text { Prob(F-statistic) }\end{array}$ & $\begin{array}{l}3.149950 \\
0.041174\end{array}$ & Durbin-Watson stat & 2.365480 \\
\hline
\end{tabular}

Pada output diatas menunjukan bahwa nilai F-statistic sebesar 3.149950, sementara F Tabel dengan tingkat $=5 \%$, df1 $(k-1)=(6-1)=5$ dan df2 $(n-k)=(40-6)=34$ didapat nilai $F$ Tabel sebesar 2,49. Dengan 
demikian F-statistic (3.14995) > F Tabel (2.49) dan nilai Prob (F-statistic) $0.041174<0.05$ maka dapat disimpulkan bahwa Ha diterima, maka dapat disimpulkan bahwa variabel independen dalam penelitian ini yang terdiri dari Leverage, Profitabilitas, Likuiditas, Ukuran Perusahaan, Umur Perusahaan secara bersama-sama memiliki pengaruh terhadap Pengungkapan Laporan Keuangan.

\section{Uji $\mathbf{R}^{2}$ (Koefesien Determinasi)}

\begin{tabular}{|lrlr|}
\hline \hline R-sauared & 0.529408 & Mean dependent var & 0.812500 \\
\hline Adiusted R-souared & 0.361339 & S.D. dependent var & 0.097164 \\
\hline S.E. of regression & 0.077650 & Akaike info criterion & -2.029895 \\
Sum squared resid & 0.084412 & Schwarz criterion & -1.731176 \\
Log likelihood & 26.29895 & Hannan-Quinn criter. & -1.971582 \\
F-statistic & 3.149950 & Durbin-Watson stat & 2.365480 \\
Prob(F-statistic) & 0.041174 & & \\
\hline \hline
\end{tabular}

Pada tabel diatas menunjukkan bahwa nilai $R$-squared sebesar 0.361339, artinya bahwa variasi perubahan naik turunnya Pengungkapan Laporan Keuangan dapat dijelaskan oleh Leverage, Profitabilitas, Likuiditas, ukuran perusahaan, Umur Perusahaan sebesar $36 \%$, sementara sisanya yaitu sebesar $64 \%$ dijelaskan oleh variabelvariabel lain yang tidak diteliti dalam penelitian ini.

\section{Uji t}

\begin{tabular}{crrrr}
\hline \hline Variable & Coefficient & Std. Error & t-Statistic & Prob. \\
\hline \hline C & -0.705617 & 0.460436 & -1.523498 & 0.1477 \\
X05 & -0.008759 & 0.037778 & -0.231844 & 0.8200 \\
X04 & 0.043943 & 0.058183 & 0.755249 & 0.4626 \\
X03 & 0.001831 & 0.012692 & 0.144256 & 0.8874 \\
X02 & 0.051679 & 0.015744 & 3.282375 & 0.0055 \\
X01 & 0.000669 & 0.001556 & 0.430054 & 0.6737
\end{tabular}

Berdasarkan table diatas diperoleh nilai t-statistic Leverange (X01) sebesar 0,430054, sementara t Tabel dengan tingkat $\alpha=5 \%$, df $(n-k)=$ $(40-6)=34$ didapat nilai t Tabel sebesar 2.03224. Dengan demikian tstatistic X01 $(0,430054)<\mathrm{t}$ Tabel (2.03224) dan nilai Prob. $0.6737>$ 0.05. Maka dapat disimpulkan bahwa variabel leverange tidak memiliki pengaruh terhadap pengungkapan laporan keuangan.

Nilai t-statistik Probabilitas (X02) sebesar 3,282375, sementara t Tabel dengan tingkat $=5 \%$, df $(n-k)=34$ didapat nilai $t$ Tabel sebesar 2.03224. Dengan demikian t-statistic X02 (3.282375) > t Tabel (2.03224) dan nilai Prob. $0.0055<0.05$, dengan nilai koefesien variabel X02 sebesar 0.051679. Maka dapat disimpulkan bahwa variabel probabilitas memiliki pengaruh positif terhadap pengungkapan laporan keuangan.

Nilai t-statistik Likuiditas (X03) sebesar 0.144256, sementara t Tabel dengan tingkat $=5 \%$, df $(n-k)=34$ didapat nilai t Tabel sebesar 2.03224. Dengan demikian t-statistic X03 (0.144256) < t Tabel (2.03224) dan nilai Prob. $0.8874>0.05$. Maka dapat disimpulkan bahwa variabel likuiditas tidak memiliki pengaruh terhadap pengungkapan laporan keuangan.

Nilai t-statistik Ukuran Perusahaan (X04) sebesar 0.755249, sementara t Tabel dengan tingkat $=5 \%$, df $(n-k)=34$ didapat nilai $t$ Tabel sebesar 2.03224. Dengan demikian t-statistic X04 (0.755249) > t Tabel (2.03224) dan nilai Prob. $0.4626>0.05$. Maka dapat disimpulkan bahwa variabel ukuran perusahaan tidak memiliki pengaruh terhadap pengungkapan laporan keuangan. 
Nilai t-statistik Umur Perusahaan (X05) sebesar -0.231844, sementara $\mathrm{t}$ Tabel dengan tingkat $=5 \%$, df $(n-k)=34$ didapat nilai $t$ Tabel sebesar 2.03224. Dengan demikian t-statistic X5 $(-0.231844)<\mathrm{t}$ Tabel (2.03224) dan nilai Prob. $0.8200>0.05$. Maka dapat disimpulkan bahwa variabel umur perusahaan tidak memiliki pengaruh terhadap pengungkapan laporan keuangan.

\section{E. Persamaam Model Regresi Data Panel}

Fungsi persamaan regresi adalah untuk memprediksi nilai variabel dependen $(Y)$ dan untuk mengetahui arah dan besarnya pengaruh variabel independen $(X)$ terhadap variabel dependen $(Y)$. Berikut nilai coeffecient yang diperoleh:

$\begin{array}{ll}\text { Variabel } & \text { Coeffecient } \\ \text { C } & -0.705617 \\ \text { X01 } & 0.000669 \\ \text { X02 } & 0.051679 \\ \text { X03 } & 0.001831 \\ \text { X04 } & 0.043943 \\ \text { X05 } & -0.008759\end{array}$

sebagai berikut:

Hasil persamaan regresi yang diperoleh:

$Y=-0.705617+0.000669+0.051679+$ $43943-0.008759+\varepsilon$

Persamaan regresi diatas memiliki makna

a. Nilai konstanta $=-0.705617$ bernilai negatif. Hal ini mengindikasikan Pengungkapan Laporan Keuangan sebesar -0.705617 dengan ketentuan apabila tidak ada variabel independen $\left(X_{1}, X_{2}, X_{3}, X_{4}, X_{5}=0\right)$

b.Nilai koefesien regresi variabel Leverage (X01) positif sebesar 0.000669. hal ini berarti setiap kenaikan Leverage 1\% akan diikuti oleh kenaikan Pengungkapan Laporan Keuangan sebesar 0.000669.

c. Nilai koefesien regresi variabel Profitabilitas (X02) positif sebesar 0.051679. hal ini berarti setiap kenaikan Profitabilitas $1 \%$ akan diikuti oleh kenaikan Pengungkapan Laporan Keuangan sebesar 0.051679.

d. Nilai koefesien regresi variabel Likuiditas (X03) positif sebesar 0.001831 . hal ini berarti setiap kenaikan Likuiditas $1 \%$ akan diikuti oleh kenaikan Pengungkapan Laporan Keuangan sebesar 0.001831.

e. Nilai koefesien regresi variabel Ukuran Perusahaan (X04) positif sebesar 0.043943. hal ini berarti setiap kenaikan Ukuran Perusahaan $1 \%$ akan diikuti oleh kenaikan Pengungkapan Laporan Keuangan sebesar 0.043943 .

f. Nilai koefesien regresi variabel Umur Perusahaan (X05) negatif sebesar -0.008759 . hal ini berarti setiap kenaikan Umur Perusahaan $1 \%$ akan diikuti oleh penurunan Pengungkapan Laporan Keuangan sebesar -0.008759 .

\section{F. Interpretasi Hasil}

1. Leverage menunjukkan koefesien positif 0.000669 dengan tingkat signifikasi sebesar $0.6737>\alpha=0.05$. Hal ini berarti $\mathrm{H}_{1}$ ditolak sehingga kesimpulannya adalah leverage tidak memiliki pengaruh 
terhadap pengungkapan laporan keuangan. Hasil ini didukung oleh penelitian yang dilakukan oleh Kartika (2009) yang menyatakan bahwa leverage tidak berpengaruh terhadap pengungkapan laporan keuangan

2. Profitabilitas menunjukkan koefesien positif 0.051679 dengan tingkat signifikasi sebesar $0.0055<\alpha=0.05$. Hal ini berarti $\mathrm{H}_{2}$ diterima sehingga kesimpulannya adalah profitabilitas memiliki pengaruh positif terhadap pengungkapan laporan keuangan. Hal ini didukung oleh penelitian yang dilakukan oleh Nugroho (2018) yang menyatakan profitabilitas memiliki pengaruh positif terhadap pengungkapan laporan keuangan.

3. Likuiditas menunjukkan tingkat koefesien positif 0.001831 dengan tingkat signifikasi sebesar $0.8874>\alpha=0.05$. Hal ini berarti $\mathrm{H}_{3}$ ditolak sehingga kesimpulannya adalah likuiditas tidak memiliki pengaruh terhadap pengungkapan laporan keuangan. Hasil ini didukung oleh penelitian yang dilakukan oleh Pratiwi (2015) yang menyatakan bahwa likuiditas tidak memiliki pengaruh terhadap pengungkapan laporan keuangan.

4. Ukuran Perusahaan menunjukkan tingkat koefesien positif 0,043943 dengan tingkat signifikasi sebesar $0.4626>\alpha=0.05$. Hal ini berarti $\mathrm{H}_{4}$ ditolak sehingga kesimpulannya adalah ukuran perusahaan tidak memiliki pengaruh terhadap pengungkapan laporan keuangan. Hasil ini didukung oleh penelitian yang dilakukan oleh Maharani dan Budiasih (2016) yang menyatakan bahwa ukuran perusahaan tidak memiliki pengaruh terhadap pengungkapan laporan keuangan.

5. Umur Perusahaan memiliki tingkat koefesien negatif -0.008759 dengan tingkat signifikasi sebesar $0.8200>\alpha=0.05$. Hal ini berarti $\mathrm{H}_{5}$ ditolak sehingga kesimpulannya adalah umur perusahaan tidak memiliki pengaruh terhadap pengungkapan laporan keuangan. Hasil ini didukung oleh penelitian yang dilakukan oleh Dewi dan Ratih (2018) yang menyatakan bahwa umur perusahaan tidak memiliki pengaruh terhadap pengungkapan laporan keuangan.

\section{KESIMPULAN}

Berdasarkan hasil analisis dan uji hipotesis yang dilakukan, dapat disimpulkan bahwa: leverage, profitabilitas, likuiditas, ukuran perusahaan, dan umur perusahaan berpengaruh signifikan terhadap Pengungkapan Laporan Keuangan. Secara parsial leverange, likuiditas, ukuran perusahaan, dan umur perusahaan likuiditas tidak memiliki pengaruh terhadap pengungkapan laporan keuangan sedangkan profitabilitas memiliki pengaruh positif terhadap pengungkapan laporan keuangan.

Berdasarkan hasil penelitian yang telah dilakukan, saran yang dapat peneliti berikan adalah sebagai berikut:

1. Bagi perusahaan sebaiknya memperhatikan kriteria yang dipakai dalam pengungkapan laporan keuangan agar dapat menyajikan kinerja perusahaan dengan baik dan benar. 
2. Bagi para investor sebaiknya melakukan analisis laporan tahunan perusahaan sebelum berinvestasi agar dapat mengambil keputusan dengan tepat.

3. Bagi peneliti selanjutnya sebaiknya meneliti lebih jauh faktor-faktor lain yang dapat menambah bahan analisis agar prediksi pengungkapan laporan keuangan dapat dilakukan lebih tepat dan akurat.

\section{DAFTAR PUSTAKA}

Pratiwi, Ririh Dian (2015). Faktor-Faktor Yang Mempengaruhi Kelengkapan Pengungkapan Laporan Keuangan. Jurnal Dinamika Akuntansi, Vol.7, No.1, Maret 2015, PP 85-97. ISSN 2085-4277.

Maharani, Luh Gede Putri dan Budiasih, I.G.A.N. (2016). Pengaruh Ukuran, Umur Perusahaan, Struktur Kepemilikan, dan Profitabilitas Pada Pengungkapan Wajib Laporan Keuangan. E-Jurnal Akuntansi Universitas Udayana, Vol.14.1 Januari 2016:34-52. ISSN: 23031018.

Santioso, Linda dan Yenny (2012). Faktor-Faktor Yang Mempengaruhi Kelengkapan Pengungkapan Wajib Dalam Laporan Keuangan Pada Perusahaan Manufaktur Yang Terdaftar Di BEl. Journal The Winner, Vol.13 No.2, September 2012: 81-92.

Agustina, Titin dkk. (2016). Faktor-Faktor Fundamental Yang Mempengaruhi Kelengkapan Laporan Keuangan Perusahaan (Studi Empiris Pada Perusahaan Manajemen".

Dewi, Rusika Martha dan Ratih, Eka Sari (2018). Faktor-Faktor Yang Mempengaruhi Kelengkapan Penggungkapan Pengungkapan Laporan Keuangan Pada Perusahaan Manufaktur Sektor Industri Dasar dan Kimia Yang Terdaftar di Bursa Efek Indonesia (BEI) Periode 2013-2016". Jurnal Akuntansi Universitas Maritim Raja Ali Haji.

Nugroho. Tri Sunu Akbar (2018). Pengaruh Profitabilitas, Leverage, Struktur Kepemilikan dan Status Perusahaan Terhadap Pengungkapan Laporan Keuangan (Studi Empiris Pada Perusahaan Manufaktur Yang Terdaftar di Bursa Efek Indonesi Tahun 20132016). Skripsi. Lampung: Universitas Lampung.

Kartika, Andi (2009). Faktor-Faktor Yang Mempengaruhi Kelengkapan Pengungkapan Laporan Keuangan Pada Perusahaan Manufaktur Yang Terdaftar Di Bursa Efek Indonesia. Kajian Akuntansi, Pebruasi 2009, Hal: 29-47, Vol.1 No.1. ISSN: 1979- 4886.

Alim. Mulia dan Ida (2018). Faktor-Faktor Yang Mempengaruhi Pengungkapan Laporan Keuangan. Jurnal Manajemen Bisnis, Vol.7 No.2, Hal.81-88. ISSN: 2302-3449. E-ISSN: 2580-9490.

Pradipta, Fairuz dkk (2016). Pengaruh Ukuran Perusahaan, Leverage, Profitabilitas, dan Likuiditas Terhadap Luas Pengungkapan Wajib Laporan Keuangan (Studi Empiris Pada Perusahaan Manufaktur 
Yang Terdaftar di Bursa Efek Indonesia Tahun 2013-2014). Jurnal Administrasi Bisnis (JAB), Vol.36 No.1 Juli 2016.

Pundawuri, Arum (2012). Pengaruh Profitabilitas, Status Kepemilikan, dan

Status Perusahaan Terhadap Pengungkapan Laporan Keuangan

Pada Perusahaan Manufaktur di Indonesia. Skripsi. Semarang: Universitas Diponegoro.

Neliana, Tri (2017). Faktor-Faktor Yang Mempengaruhi Tingkat Kelengkapan Perungkapan Laporan Keuangan. Jurnal Riset dan Akuntansi, Vol.5 (2), 2017, 1409-1422.

Retnoningsih (2013). Analisis Faktor-Faktor Yang Mempengaruhi Luas Pengungkapan Laporan Tahunan (Studi Empiris Pada Perusahaan Manufaktur Yang listing di Bursa Efek Indonesia Periode 2009-2011).

Skripsi. Yogyakarta: Universitas Negeri Yogyakarta

www.idx.com

http://amp.kontan.co.id/news/ojk-sedang-menangani-46-kasus-

pasarmodal,diakses pada 12 Februari 2020.

http://m.detik.com/finance/moneter/d-4159957/ojk-lakukan-21-

pemeriksaan-dugankasus-goreng-saham, diakses pada 12 Februari 2020.

https://mjurnal.com/uji-asumsi-klasik-menggunakan-eviews/, diakses pada 16 Juni 2020.

https://dimasrovio.blogspot.com/2017/11/uji-asumsi-klasik-

heteroskedastisitas.html, diakses 16 Juni 2020.

https://mjurnal.com/cara-baca-hasil-regresi-eviews-interpretasi-hasil-

regresi/, diakses 17 Juni 2020. 